\title{
PHILIPPIANS: FROM PEOPLE TO LETTER ${ }^{1}$
}

\section{Peter Oakes}

This thesis explores the idea of listening to Philippians from the viewpoint of reconstructions of its first recipients. It first considers the development of the Roman colony of Philippi and the social composition of a church likely to arise in that context. It then defends the idea that there was suffering in the Philippian church and considers the probable nature of that in the social setting of Philippi. The model of the hearers developed in this way is put to work in three key exegetical areas. First, two imaginary hearers, one suffering and one not, listen to the letter-in particular to the material on the major theme of suffering. Second, the Philippian Christians listen to material on Christ's Lordship in the light of their experience of Imperial ideology. Third, the preceding work is drawn together as the Philippians listen to the juxtaposition, in 2:1-11, of the themes of suffering and unity.

The first three chapters are introductory and historical. One major conclusion is that most Philippian Christians were probably Greeks and not Roman citizens. Chapter four defends the conclusion that Christians at Philippi were suffering. The most likely source of suffering would be opposition engendered by Christians ceasing to honour the gods and persuading others to do the same. Also, once some Christians became known as troublemakers, others would face opposition if they associated with them. The most probable form of suffering would be breakdown of relationships, often leading to economic suffering.

Chapter five reconstructs two imaginary Philippian hearers of the letter, Jason and Penelope. Jason has suffered a great deal; Penelope, very little. I imagine how each of these

1Peter Oakes, Philippians: From People to Letter (unpublished D.Phil. thesis, University of Oxford, 1995); supervisor: Dr N.T. Wright. 
might have heard the letter. Jason was waiting to hear from his suffering hero. In 1:1-11, he heard Paul expressing warmth towards the Philippians as they shared with him in similar experiences of suffering. Penelope was waiting to hear from the missionary she supported. In 1:1-11, she heard Paul expressing appreciation for their financial support. Each hearer 'filled in' relatively open terms from their own perspective. This raises questions about whether Paul might be deliberately leaving the terms open.

In 1:12-26, Penelope heard a 'missionary report'; Jason heard a model for behaviour under suffering. In 1:27-2:18, Penelope was disturbed as Paul sided with those suffering; Jason was encouraged. In 2:19-30, the travel plans took on weighty significance as Penelope wondered what Timothy would expect to find in Philippi. He was due to report back to Paul (2:19). Listening to Philippians 3-4 from the perspectives of characters oriented around the theme of suffering, which runs right through the letter, shows that much of the material in the letter can be drawn together.

The starting point for chapter six is the recognition that 2:9-11 represents a granting of authority rather than simply reward or vindication. For the Philippian hearers, a natural point of comparison for this is the Emperor. Moreover, 'therefore' in 2:9 represents that authority as having been granted for a reason. We should, then, consider what were seen in the first century as factors which properly legitimated the granting of extensive authority. This points us towards the Roman Imperial ideology to which the Philippians would have been exposed.

In $3: 20-21$, the context of the references to Christ is political, the topic being ethics defined by allegiance to an alternative state. In such a context, a 'saviour' who comes from that state to rescue his people is bound to be heard as a comparison with the Emperor. This is brought home by Christ's action in accordance with the power by which he subjects all things to himself. 2:9-11 is conceptually and verbally linked to 3:20-21. 2:9-11 presents Christ as acceding to an authority which includes the Emperor's sphere but goes beyond it. Divine figures who might be alternative points of comparison for 
heavenly authority would either not be uniformly recognised by the Philippians as having universal authority or do not fit the picture presented by 2:9-11.

'Therefore' in 2:9 supports the comparison. The importance of selfless moral excellence in legitimating the authority of an emperor makes 2:6-8 a very natural legitimation of 2:9-11 in the Roman context. The parallel with the Emperor is strengthened by the role of naming in 2:9 and by the title 'Lord'. If the cosmos is saved in 2:10, the parallel is further strengthened because Christ is carrying out the central Imperial task of bringing salvation by universal submission. 2:10 also quotes Isaiah 45:23. The picture there is of God as Emperor on his throne, with the nations coming to do homage. Paul places Christ on this Imperial throne.

The final chapter considers the way in which the theme of suffering and the appeal to unity are intertwined in 1:27-2:11. The chapter considers how the Philippians are likely to have heard 2:1-4 and the ways in which 2:5-11 could have functioned to reinforce the call of the preceding verses. The intertwining of the issues of suffering and unity is first placed in the context of Philippi. Suffering-especially economic suffering-increases the need for unity, particularly in terms of mutual financial support. Putting this into effect would be difficult in the Graeco-Roman setting, given the social imperative of maintaining one's present level of wealth and one's present economic relationships. Suffering would make maintenance of unity more difficult.

The main implication of $1: 27-30$ for $2: 1-4$ is that the unity at issue is unity under opposition and suffering. The particular list of benefits and attitudes in 2:1 sets up an expectation that Paul will call for a demonstration of these towards others by practical help. The call to unity in 2:2, however, goes beyond what would be expected in GraecoRoman society. Mutual support in a group covering a range of statuses would normally be in the form of patronal relationships. What Paul calls for sounds more like friendship between social equals. 2:4, the end-point of Paul's plea, is about concern for the interests of others. In a suffering church, this probably means provision of practical support. 
The Philippians, who have heard Paul's call to 'humility', etc. in 2:1-4 and then hear Christ's story of willing loss of status and acceptance of suffering, are bound to perceive the story in 2:6-8 as an example. To suppose otherwise requires an implausible theological sophistication among the Philippians.

The Philippians, having mentally followed Christ's descent to the Cross, and having resolved to follow him, seem bound to hear the announcement in 2:9-11 of his consequent exaltation as carrying some promise of reward for them. This stands in some tension with the uniqueness of the position to which Christ is raised, but a comparison between Christ and the Emperor would diffuse the tension. The coming to power of an Emperor brings reward to his followers.

Christ's raising to universal sovereignty could function among the Philippians in several ways. Christ's authority would relativise competing authorities that produced imperatives contradictory to his. In 2:1-4, the contradictory imperatives would be those of Philippian society, working against unity under suffering. In that case, for Christ to have an authority which was specifically heard as relativising that of the Emperor would be especially relevant. Such a socio-political comparison would be far more relevant to a reinforcement of 2:1-4 than would a purely religious one. There are no signs that religious issues are involved in the situation of 2:1-4. Following Christ's way also becomes the one secure path because only Christ has the power to provide security. The Christian community is also de-marginalised (cf. 2:15-16). If 2:9-11 function in these kinds of ways, they again form an apposite reinforcement to 2:1-4, overcoming the kinds of pressure that would work against acceptance of Paul's exhortation. 